\title{
THE SIGNIFICANTLY VIABLE PARTICLE: A STUDY OF THE SUBCULTURE OF AN EXACTING SPORING ANAEROBE
}

\author{
J. G. Collee, J. M. Rutter* AND B. Watt \\ Department of Bacteriology, University Medical School, Edinburgh
}

FAILURE to obtain consistently reliable growth of Clostridium oedematiens (Cl. novyi) of types B, C and D on the surface of solid media has been reported by many workers. For example, Albiston (1927) was unable to grow a type-B strain on solid media; Keppie (1944) worked with $\mathrm{Cl}$. oedematiens-infected tissues and often failed to culture type-B strains on plates of agar media. Williams $(1962,1964)$ commented on frequent failures of isolation of type-B and type-D strains on solid media; and Willis (1969) observed that type-B strains are more difficult to grow than type-A strains, whilst " type D strains are probably the most fastidious anaerobes known".

The reasons for the particularly exacting nature of type-B and type-D strains on solid media are not understood, and the various methods that have been suggested to facilitate culture of $\mathrm{Cl}$. oedematiens reflect diverse views. Smith's (1955) use of shake tubes, pourplates or subsurface cultures implies that protection against exposure to oxygen is important, whereas his faith in fresh brain infusion as a supplement seems to indicate concern for nutrition. Willis $(1964$, p. 83$)$ suggested that $\mathrm{Cl}$. oedematiens is so sensitive to oxygen that it dies unless plates are seeded and placed in anaerobic jars immediately. Moore (1968) found that the presence of cysteine and either ascorbic acid, thioglycollate or dithiothreitol is essential for consistent, rapid and luxuriant surface growth of type-B strains; culture procedures should now be re-assessed with particular reference to this observation.

In the literature on the culture of $\mathrm{Cl}$. oedematiens, it is not clear whether surface growth is initiated from vegetative organisms or from spores. Smears prepared from pathological material or from fluid cultures that contain $\mathrm{Cl}$. oedematiens usually show both spores and vegetative forms, and it seems reasonable to suppose that a fraction of the inoculum should be viable on solid media if the cultural conditions allow germination and outgrowth of the spores. The present study was designed to examine some of the problems involved in the laboratory subculture of the exacting types of $\mathrm{Cl}$. oedematiens. At first it was necessary to pay particular attention to details of anaerobic jar procedure. Growth on various solid media was then assessed. At this stage, Moore's report was published and it was possible to extend the study in the light of his significant contribution.

\section{MATERIALS AND METHODS}

\section{General considerations}

Strains. Twenty strains of $\mathrm{Cl}$. oedematiens representative of types A, B, C and D were kindly provided by Mr J. R. Hepple. Some of these strains originated from the National

Received 7 July 1970; accepted 10 Dec. 1970.

* Present address: ARC Institute for Research on Animal Diseases, Compton, Berkshire.

J. MED. MICROBIOL.-VOL. 4 (1971) 
Collection of Type Cultures, Colindale; others were isolated at the Aberystwyth Veterinary Investigation Centre, and some belonged to the Glaxo collection. In addition, ten strains of $\mathrm{Cl}$. oedematiens were isolated from infected animal tissues kindly provided by Dr J. A. A. Watt of the Edinburgh Veterinary Investigation Centre, and 11 strains came from the collection of Dr Nancy J. Hayward. All of the above strains were lyophilised as soon as their purity and identity had been confirmed; thereafter, the strains were subcultured in cooked-meat broth and frequent checks of purity and identity were made.

Serological neutralisation test. Procedures developed by Rutter and Collee (1969) were used for checking the identity of the test strains.

Culture media. Cooked-meat broth (CMB) was used as a routine in the present study; nutrient broth (Oxoid) replaced peptone infusion broth in the preparation of this medium (Cruickshank, 1968, p. 757), but the meat particles were prepared in this department. Simple nutrient broth, Reinforced Clostridial Medium and Brewer Medium were supplied by Oxoid; some test media were supplemented with Oxoid peptone and Oxoid yeast extract (see text).

Blood agar plates were prepared with Oxoid Blood Agar Base no. 2 enriched with horse or human blood to 10-20 per cent. as specified in the text. The agar concentration was 1.2 per cent. New Zealand Davis agar. Control blood agar plates used in comparative studies with CDHBA33 medium (see below) contained 33 per cent. blood.

\section{Watt's modifications of Moore's medium (cysteine-dithiothreitol human blood agar, $C D H B A$ )}

$C D H B A 16$. The following solution is prepared immediately before use and sterilised by Millipore filtration: cysteine hydrochloride (Koch-Light) $100 \mathrm{mg}$ per ml, dithiothreitol pure (Koch-Light) $9 \mathrm{mg}$ per ml, in distilled water. To $100 \mathrm{ml}$ of sterile melted Blood Agar Base no. 2 (Oxoid) at $45^{\circ}-50^{\circ} \mathrm{C}$ is added $20 \mathrm{ml}$ human blood and $1 \mathrm{ml}$ of the cysteine-dithiothreitol solution. The medium is mixed by careful inversion and plates are poured. When the plates have set, their surfaces are dried in a hot-air cabinet at approximately $60^{\circ} \mathrm{C}$ for $10 \mathrm{~min}$., and they are then used immediately. The final concentration of ingredients in this medium was cysteine hydrochloride $82 \mathrm{mg}$ per $100 \mathrm{ml}$, dithiothreitol $7.5 \mathrm{mg}$ per $100 \mathrm{ml}$, and human blood 16 per cent.

$C D H B A 33$. In a later modification, pure cysteine (Koch-Light) $50 \mathrm{mg}$ per $\mathrm{ml}$ was used in place of cysteine hydrochloride and the concentration of the dithiothreitol was reduced to $4.5 \mathrm{mg}$ per $\mathrm{ml} ; 2 \mathrm{ml}$ of this mixture was added to $66 \mathrm{ml}$ of 1.5 -strength melted Oxoid Blood Agar Base no. 2 at $45^{\circ}-50^{\circ} \mathrm{C}$. At this stage, $33 \mathrm{ml}$ human blood was added and the medium was prepared as above. This medium contained cysteine $100 \mathrm{mg}$ per $100 \mathrm{ml}$; dithiothreitol $9 \mathrm{mg}$ per $100 \mathrm{ml}$; and human blood 33 per cent.

Blood. Defibrinated horse blood was supplied by Wellcome Laboratories. Citrated human blood (outdated) was obtained from the Blood Transfusion Department, Edinburgh Royal Infirmary.

Anaerobic culture procedure. Culture media were incubated as a routine at $37^{\circ} \mathrm{C}$ in anaerobic jars with a room-temperature catalyst sachet (Baird and Tatlock); carbon dioxide (10 per cent.) and hydrogen were used. The detailed procedure is given in the text. In the final series of experiments, each of the anaerobic jars was fitted with three catalyst sachets.

Gases. Cylinders of hydrogen gas were supplied by British Oxygen; carbon dioxide was obtained from Distillers Company Ltd (D.C.L.).

\section{Metals}

Particulate iron. Crude " iron filings" were initially supplied from local laboratory stock. Particulate iron was subsequently obtained as the following BDH preparations: (i) iron powder (electrolytic), (ii) iron metal powder about 90 mesh, and (iii) iron metal powder reduced by hydrogen.

Other particulate metals. Manganese powder and finely powdered nickel were obtained from Messrs Hopkin and Williams Ltd, Chadwell Heath, Essex. 


\section{Counting methods}

Total counts of bacteria were initially performed in a Helber bacterial counting chamber (Hawksley Ltd) with a Thoma ruling and $0.02 \mathrm{~mm}$ depth; at least 400 bacteria were counted. Two or more independent counts were performed by two observers in each experiment and the results were collated. Bacteria were allowed to settle in the chambers for c. $5 \mathrm{~min}$. before enumeration. In the later part of this study, we took account of the observations of Norris and Powell (1961) and Cook and Lund (1962), and a Hawksley (B.S. 748) counting chamber of $0.1 \mathrm{~mm}$ depth was used. Counts were made with phase-contrast microscopy. A chain of organisms was counted as one colony-forming unit (cfu). The number of spores was estimated during the total count procedure and spores were also enumerated in separate thin wet films. The spore content of cultures was checked by preparing stained smears in which free spores were more readily visible (see below).

Viable counts were performed with the shake-culture, pour-plate or spread-plate methods, as indicated. Dilutions of the bacterial culture were prepared with sterile presteamed cooked-meat broth supernatant or presteamed nutrient broth as the diluent. Gentle mixing during the dilution procedures minimised aeration. An appropriate volume of each dilution was added to the cooling culture medium at $45^{\circ} \mathrm{C}$ and the deep colonies that appeared after anaerobic incubation were counted with a mechanical colony counter. Pour-plates were prepared from Oxoid Reinforced Clostridial Medium (RCM) with human blood added to 5 per cent. Spread plate (surface) counts were derived from $0.02-\mathrm{ml}$ inocula of dilutions made in presteamed nutrient broth (Oxoid no. 2) and dropped from standard calibrated pasteur pipettes; the drops were spread in a standard manner with sterile glass spreaders of uniform size. Viable counts were calculated as the average result of at least two plates for each dilution, and this figure was multiplied by the appropriate dilution factor. The " most reliable estimate" was obtained from the dilution that gave the maximum countable number of evenly distributed colonies in the range of 100-500 colonies per plate.

Spore studies. Estimates of spore numbers were based on observations of Gram-stained smears and of smears stained for spores by the malachite green procedure of Ashby (see Cruickshank, p. 657); occasional checks were made with an acid-fast staining procedure in which nitric acid 2 per cent. in absolute ethyl alcohol was used as the decolorising agent (Cruickshank, p. 657).

\section{RESULTS}

\section{Difficulties encountered in the culture of Clostridium oedematiens}

Strains of $\mathrm{Cl}$. oedematiens of types A, B, C and D grow well in anaerobically incubated cooked-meat broth (CMB) prepared as described by Cruickshank (p. 757). These organisms did not grow consistently from similar inocula in tubes containing 10-ml volumes of nutrient broth (Oxoid), but growth was regularly successful when $1-\mathrm{ml}$ inocula from $20-\mathrm{hr}$ CMB cultures were grown in freshly prepared $100-\mathrm{ml}$ volumes of nutrient broth that were steamed and cooled to $37^{\circ} \mathrm{C}$ just before inoculation of the organisms; the bottles were then incubated in an anaerobic jar. In the following studies, the inocula were obtained from 1-4-day-old CMB cultures.

"Shake cultures", i.e., cultures grown in bottled agar media seeded with $0 \cdot 5-\mathrm{ml}$ inocula just before solidification, were frequently successful with strains of all types. Experiments with various permutations of ingredients in deep agar media showed that relatively simple combinations of peptone and yeast extract supported growth. However, with the exception of type-A strains, growth was not prolific; sometimes only one or two colonies developed. Pour-plates prepared from nutrient agar with added blood (10-20 per cent.) and incubated anaerobically gave irregular and often poor results. Human blood was more 
effective than horse blood. When the blood agar medium was made with Reinforced Clostridial Medium (RCM, Oxoid), growth in the pour-plates was much more reliable and we then found that although the blood was not essential, the associated haemolysis facilitated colony detection. The common factor in those systems that supported growth seemed to be the exclusion of air and the production of an adequately reducing environment.

Attempts to grow surface colonies on solid media that were based on the above findings were disappointing. Strains of type A grew readily and profusely on the enriched media, and some growth was even obtained on simple nutrient agar. However, successful growth of strains of types B, C and D was irregularly obtained on various enriched media and on nutrient agar containing 20 per cent. of human blood (see Rutter, 1968); the colonies were usually few and plates frequently showed no growth. It therefore seemed necessary to determine whether our anaerobic jar procedure was reliable.

\section{An appraisal of anaerobic jar procedure}

There are several interpretations of the degree of evacuation involved in the procedure for setting up a BTL anaerobic jar (Baird and Tatlock Ltd) that incorporates a room-temperature catalyst. The literature supplied with the jar recommends that $\frac{6}{7}$ of the air should be removed before hydrogen is admitted, but Willis (1964, p. 10), Collee (1968) and Meynell and Meynell (1970) suggest that only $\frac{2}{5}-\frac{3}{5}$ of the air should be evacuated. Each of the recommended procedures is consistent with regard to the demonstration of catalyst activity; hydrogen is admitted to the jar via a Woulff bottle, and after the initial inrush of gas, hydrogen continues to flow into the jar in order to equalise the sub-atmospheric pressure that is produced when the hydrogen and residual oxygen combine in the presence of an active catalyst. The internal pressure changes that occur in such jars can be demonstrated more precisely with a suitable manometer; this technique was preferred during the present study and it had the added advantage of introducing a relatively dry gas into the jar (q.v.).

Considerable pressure changes occur in a jar equipped with an active catalyst if $\frac{2}{5}$ of the air is removed during the evacuation stage; oxygen that is present in the remaining $\frac{3}{5}$ of the air is available for combination with hydrogen and the secondary vacuum that develops in the jars can be recorded on a relatively insensitive vacuum gauge. Much less oxygen is available to combine with hydrogen in jars from which $\frac{6}{7}$ of the air has been evacuated, and a mercury manometer was used to demonstrate the small pressure changes that occur in these jars during the gaseous reaction. In a series of tests over a long period, it was found that the rapid development of a secondary vacuum in the anaerobic jar is a satisfactory indication that the room-temperature catalyst is active.

\section{Standardisation of the anaerobic jar procedure}

In order to standardise the anaerobic jar procedure, the following technique was adopted in the present study: $\frac{6}{7}$ of the air was evacuated from each jar 
and the resulting reduced pressure ( $100 \mathrm{~mm} \mathrm{Hg}$, i.e., $660 \mathrm{~mm}$ below atmospheric) was brought up to $160 \mathrm{~mm} \mathrm{Hg}(600 \mathrm{~mm}$ below atmospheric) with carbon dioxide and then to $760 \mathrm{~mm} \mathrm{Hg}$ (i.e., atmospheric) or a slightly higher pressure with hydrogen, each from separate rubber bladders. These procedures were monitored on a vacuum gauge. The jar was then connected to a simple mercury manometer; initially, the pressure within each jar was slightly above atmospheric, depending on the pressure of the gas supply via the rubber bladder, but if the catalyst is normally active, a decrease in pressure of at least $10-20 \mathrm{~mm}$ of mercury occurs within $10 \mathrm{~min}$. after the admission of hydrogen. At this stage, more hydrogen is introduced to equilibrate the pressure and the jar is then incubated at $37^{\circ} \mathrm{C}$. Control experiments showed that a sub-atmospheric pressure develops after several hours in jars without a room-temperature catalyst; thus, the rapid development of an internal pressure change is important.

The problems associated with the sensitivity and significance of anaerobic indicators merit further attention. We eventually discontinued the use of any indicator in this study.

\section{A re-appraisal of problems associated with the subculture of $\mathbf{C l}$. oedematiens}

The standard anaerobic jar procedure made it possible to subculture type-A strains from CMB medium on blood agar reliably, yet growth of types B, C and $\mathrm{D}$ on solid media continued to be most unreliable. It seems reasonable to expect that, if the inoculum contains spores, and if cultural conditions permit their germination and outgrowth, subculture on to solid media should be successful and the counts obtained should approach the estimated number of spores in the inoculum. Further experiments were therefore designed to investigate the relation between the spore content and the viability of inocula transferred to solid media.

\section{The viability of inocula in pour-plate cultures with particular reference to spore content}

In a series of experiments with type-A and type-B strains grown in different media for varying periods, the total cell counts of test samples were determined and the percentage of sporing forms was estimated in each case. Estimates of spore numbers were then based on these observations and compared with viable counts obtained by culturing measured volumes of serial dilutions of the test sample in pour-plates of RCM agar containing 5 per cent. of human blood to assist colony differentiation. The plates were incubated anaerobically with 10 per cent. $\mathrm{CO}_{2}$ at $37^{\circ} \mathrm{C}$ for $48 \mathrm{hr}$. The results of typical experiments are given in table I and they show that sporulation increased with the period of incubation of the culture in CMB medium. The viable counts are related to the spore estimates in that they are increased when the spore numbers are increased. However, when we experimented with a type-B strain, we were consistently unable to obtain viable counts that came within a reasonable range of the relevant spore estimates. Even if we assume that spores contribute all of the viable particles redeemed with the pour-plate technique from a 4-day CMB culture of 
the type-B strain, only a small proportion of spores $(0.4$ per cent.) proceed to germinate and form colonies. The observed discrepancies between spore counts and viable counts could have been attributable to variables in spore germination and we began a search for agents that might influence the germination and successful outgrowth of the spores.

The effect of particulate iron on the surface growth of Cl. oedematiens

During a search for substances that might influence spore germination of $C l$. oedematiens and growth of types $\mathrm{B}$ and $\mathrm{D}$ at the surface of agar media,

TABLE I

The total cell counts, spore counts and viable counts of different cultures of type-A and type-B strains of Clostridium oedematiens determined by a pour-plate procedure

\begin{tabular}{|c|c|c|c|c|c|c|}
\hline \multirow{2}{*}{$\begin{array}{l}\text { Strain and cultural } \\
\text { conditions of test } \\
\text { sample }\end{array}$} & \multirow{2}{*}{$\begin{array}{l}\text { Total } \\
\text { count } \\
\text { per ml }\end{array}$} & \multicolumn{3}{|c|}{$\begin{array}{l}\text { Percentage of sporing } \\
\text { forms as revealed by }\end{array}$} & \multirow{2}{*}{$\begin{array}{l}\text { Estimated } \\
\text { number of } \\
\text { spores } \\
\text { per ml }\end{array}$} & \multirow{2}{*}{$\begin{array}{l}\text { Viable count per ml } \\
\text { at } 48 \mathrm{hr} \text { in RCM* } \\
\text { with } 5 \text { per cent. } \\
\text { human blood }\end{array}$} \\
\hline & & $\begin{array}{c}\text { phase } \\
\text { contrast }\end{array}$ & $\begin{array}{c}\text { Gram's } \\
\text { stain }\end{array}$ & $\begin{array}{l}\text { spore } \\
\text { stain }\end{array}$ & & \\
\hline $\begin{array}{c}\text { GRIA (type } A) \text { in } \\
C M B \text { medium } \\
\text { at } 18 \mathrm{hr} . \\
\text { at } 4 \text { days }\end{array}$ & $\begin{array}{l}1.0 \times 10^{7} \\
6.8 \times 10^{6}\end{array}$ & 66 & 65 & $\begin{array}{l}2 \cdot 0 \\
60\end{array}$ & $\begin{array}{l}2 \cdot 0 \times 10^{5} \\
4 \cdot 5 \times 10^{6}\end{array}$ & $\begin{array}{l}2 \cdot 7 \times 10^{5} \\
1 \cdot 8 \times 10^{6}\end{array}$ \\
\hline $\begin{array}{c}R 32 B \text { (type } B) \text { in } \\
C M B \text { medium } \\
\text { at } 18 \mathrm{hr} . \\
\text { at } 4 \text { days }\end{array}$ & $\begin{array}{l}4.7 \times 10^{6} \\
1.5 \times 10^{7}\end{array}$ & $\begin{array}{l}<1 \cdot 0 \\
28\end{array}$ & $\begin{array}{l}<1 \cdot 0 \\
29\end{array}$ & $\begin{array}{l}<1 \cdot 0 \\
34\end{array}$ & $\begin{array}{r}<4 \cdot 7 \times 10^{4} \\
4.3 \times 10^{6}\end{array}$ & $\begin{array}{l}2 \cdot 8 \times 10 \\
1 \cdot 7 \times 10^{4}\end{array}$ \\
\hline
\end{tabular}

* Reinforced Clostridial Medium (Oxoid).

many test reagents were added to inocula of test strains grown in CMB and plated on human blood agar. The test reagent was either mixed with the inoculum at the time of plating-out, or was added to the surface of the medium after the inoculum had been plated-out with a loop. The only material that produced a significant and marked effect on the surface growth of type-B and type-D strains was particulate iron.

$\mathrm{Cl}$. oedematiens types $\mathrm{B}, \mathrm{C}$ and $\mathrm{D}$ do not normally grow on the surface of standard horse blood agar plates. We had noted that blood agar prepared with 20 per cent. human blood produces better results, but subcultures on this medium were frequently unsuccessful or disappointingly scanty. When heatsterilised iron filings were sprinkled on blood agar plates that had been seeded with type-B or type-D strains of $\mathrm{Cl}$. oedematiens from CMB cultures, subsequent anaerobic incubation yielded consistently reliable growth of the organisms. Colonies were well developed within $24 \mathrm{hr}$ and they developed around particles of iron on the medium. Alternatively, iron filings suspended in water and sterilised in the autoclave were added as drops of suspension to the well 
of a blood agar plate and mixed with a loopful of a CMB culture of the test strain; the mixture was then plated out with a loop in the usual manner. Again, colonies developed more reliably and more rapidly; after overnight incubation, growth was clearly visible and it was undoubtedly related to the particulate iron. Iron filings from various sources (see Methods) gave comparable results. The effect could not be reproduced by substituting sterile particles of inert materials such as carbon or crushed egg-shell and we have been unable to produce such a striking effect with any other particulate metal or with solutions of metallic salts. Finely divided manganese is ineffective; equivocal but at the best insignificantly positive results were obtained with particulate nickel and palladised asbestos. The best procedure was the technique that we adopted in ignorance: the iron filings are virtually ineffective if they are incorporated in the melted agar which, on solidification, receives the inoculum. On the other hand, if the inoculum is seeded into the melted agar, the subsequent addition of the iron filings to the solidified surface stimulates the development of colonies in the underlying medium.

\section{Further studies on the nature of the viable particle}

Studies with pour-plates and iron filings. Strains of types B, C and D clearly differed from type-A strains in being much more difficult to culture on solid media, and we now omitted type-A strains from our further studies.

In the following experiments, total cell counts, spore estimates and viable counts were made on samples of each sporing culture that were (i) untreated, (ii) washed twice by centrifugation with saline and resuspended to the same volume, and (iii) treated as in (ii) and then heated for $20 \mathrm{~min}$. at $70^{\circ} \mathrm{C}$. The viable counts in this section of the work were performed by preparing pour plates of RCM agar enriched with human blood 5 per cent. and sprinkled with iron filings on the surface. The results obtained with strains representative of the three types are given in tables II and III. The range of the viable counts over the different dilutions is about 10-fold. The results that are used below refer to the "most reliable estimate" (see Methods).

With the type-B strain, the viable counts increased slightly with prolonged incubation of the pour plates. None of the viable counts approached the estimated number of spores, and the results obtained with the pasteurised sample suggest that spore recovery was 1 per cent. (table II). If we assume that none of the spores is activated or inactivated by heating at $70^{\circ} \mathrm{C}$, and if similar numbers of spores were redeemed in the untreated and the pasteurised sample, then spores could have contributed to more than 50 per cent. of the viable count of the untreated sample. By similar reasoning, spores contributed to at least 70 per cent. of the washed sample. These results imply that a considerable proportion of the vegetative cells does not grow when subcultured in pourplates.

With the type-C strain, the viable count was the same as the estimated spore count (table II). Spore recovery from the pasteurised sample was 67 per cent. Spores account for almost 70 per cent. of the viable count with the untreated sample, and 81 per cent. with the washed sample. The good recovery of spores from the pasteurised sample is interesting. It may be that germination 
requirements were met by the conditions of the experiment for this particular strain. However, this strain gave us most trouble in its inconsistent growth on solid media.

\section{TABLE II}

Viable counts by a pour-plate procedure on treated and untreated samples of $C M B$ cultures of a type-B and a type-C strain of $C l$. oedematiens, with total cell counts and spore counts of the untreated samples

\begin{tabular}{|c|c|c|c|c|c|c|}
\hline Type & $\begin{array}{l}\text { Treatment of } \\
\text { sample }\end{array}$ & $\begin{array}{l}\text { Total cell } \\
\text { count }\end{array}$ & $\begin{array}{c}\text { Observed } \\
\text { percentage } \\
\text { of spores* }\end{array}$ & $\begin{array}{c}\text { Estimated } \\
\text { number of } \\
\text { spores per ml }\end{array}$ & $\begin{array}{c}\text { Time of } \\
\text { incubation } \\
\text { (hr) }\end{array}$ & $\begin{array}{c}\text { Viable count } \dagger \\
\text { per ml in } \mathrm{RCM} \\
+5 \text { per cent. blood } \\
+ \text { iron filings }\end{array}$ \\
\hline \multirow[t]{6}{*}{ B } & \multirow[t]{2}{*}{ None } & \multirow[t]{2}{*}{$2 \cdot 0 \times 10^{7}$} & \multirow[t]{2}{*}{36} & \multirow[t]{2}{*}{$7 \times 10^{6}$} & 24 & $\begin{array}{l}1.7 \times 10^{4} \\
6.0 \times 10^{4} \\
1.5 \times 10^{5}\end{array}$ \\
\hline & & & & & 72 & $1.3 \times 10^{5}$ \\
\hline & \multirow[t]{2}{*}{$\begin{array}{l}\text { Washed and resus- } \\
\text { pended in saline }\end{array}$} & \multirow[t]{2}{*}{$\ldots$} & \multirow[t]{2}{*}{$\ldots$} & \multirow[t]{2}{*}{$\ldots$} & 24 & $\begin{array}{l}1.3 \times 10^{4} \\
4.2 \times 10^{4} \\
7.6 \times 10^{4}\end{array}$ \\
\hline & & & & & 72 & $9.4 \times 10^{4}$ \\
\hline & \multirow{2}{*}{$\begin{array}{l}\text { Washed, resus- } \\
\text { pended and } \\
\text { heated at } 70^{\circ} \mathrm{C} \\
\text { for } 20 \mathrm{~min} .\end{array}$} & \multirow[t]{2}{*}{$\ldots$} & \multirow[t]{2}{*}{$\ldots$} & \multirow[t]{2}{*}{$\ldots$} & 24 & $\begin{array}{l}1.6 \times 10^{4} \\
5.2 \times 10^{4}\end{array}$ \\
\hline & & & & & 72 & $7.0 \times 10^{4}$ \\
\hline \multirow[t]{6}{*}{$\mathrm{C}$} & \multirow[t]{2}{*}{ None } & \multirow[t]{2}{*}{$2.7 \times 10^{5}$} & \multirow[t]{2}{*}{16} & \multirow[t]{2}{*}{$4.3 \times 10^{4}$} & 48 & $\begin{array}{l}1.7 \times 10^{4} \\
\mathbf{3} \cdot \mathbf{8} \times 10^{4} \\
3.8 \times 10^{4}\end{array}$ \\
\hline & & & & & 72 & $4.2 \times 10^{4}$ \\
\hline & \multirow[t]{2}{*}{$\begin{array}{l}\text { Washed and resus- } \\
\text { pended in saline }\end{array}$} & \multirow[t]{2}{*}{$\ldots$} & \multirow[t]{2}{*}{$\ldots$} & \multirow[t]{2}{*}{$\ldots$} & 48 & $\begin{array}{l}1.3 \times 10^{4} \\
3.6 \times 10^{4} \\
3.5 \times 10^{4}\end{array}$ \\
\hline & & & & & 72 & $3.6 \times 10^{4}$ \\
\hline & \multirow{2}{*}{$\begin{array}{l}\text { Washed, resus- } \\
\text { pended and } \\
\text { heated at } 70^{\circ} \mathrm{C} \\
\text { for } 20 \mathrm{~min} .\end{array}$} & \multirow[t]{2}{*}{$\ldots$} & \multirow[t]{2}{*}{$\ldots$} & \multirow[t]{2}{*}{$\cdots$} & 48 & $\begin{array}{l}1.4 \times 10^{4} \\
2.8 \times 10^{4} \\
2 \cdot 7 \times 10^{4}\end{array}$ \\
\hline & & & & & 72 & $2.9 \times 10^{4}$ \\
\hline
\end{tabular}

* Based on the mean of separate observations with phase-contrast microscopy and stained smears.

$\dagger$ The figures, derived from results with various dilutions, are given to show the degree of variation. The "most reliable estimate" (see Methods) is given in bold type.

$\ldots=$ Not done.

With the type-D strain, spore recovery from the pasteurised sample was 13 per cent. (table III). Spores could have contributed to more than 70 per cent. of the viable count with the untreated sample and 100 per cent. with the washed sample. 
The results of the above studies indicate that in old cooked-meat broth cultures of $\mathrm{Cl}$. oedematiens subcultured to pour plates supplemented with iron filings, spores may have accounted for 50-70 per cent. or more of the viable counts. With washed inocula, spores contributed 70-100 per cent. to the viable counts. Spore recovery was poor with the type-B strain, and it may be significant that this culture was the youngest of the three that were tested.

TABLE III

The viable counts determined by a pour-plate procedure with treated and untreated samples of a CMB culture of a type-D strain incubated for $20 \mathrm{hr}$ at $37^{\circ} \mathrm{C}$ and thereafter held on the bench at room temperature for 28 days, and the total cell counts and spore counts of the untreated sample and the washed resuspended sample

\begin{tabular}{|c|c|c|c|c|c|}
\hline \multirow{2}{*}{$\begin{array}{l}\text { Pre-treatment } \\
\text { of sample }\end{array}$} & \multirow{2}{*}{$\begin{array}{l}\text { Total cell } \\
\text { count } \\
\text { per } \mathrm{ml}\end{array}$} & \multirow{2}{*}{$\begin{array}{l}\text { Observed } \\
\text { percentage } \\
\text { of spores* }\end{array}$} & \multirow{2}{*}{$\begin{array}{c}\text { Estimated } \\
\text { number of } \\
\text { spores } \\
\text { per ml }\end{array}$} & \multicolumn{2}{|c|}{$\begin{array}{l}\text { Viable count per } \mathrm{ml} \text { in } \\
\text { RCM with } 5 \text { per cent. } \\
\text { blood plus iron filings }\end{array}$} \\
\hline & & & & at $48 \mathrm{hr} \dagger$ & at $96 \mathrm{hr}$ \\
\hline Untreated & $1 \times 10^{6}$ & 41 & $4.1 \times 10^{5}$ & $\begin{array}{l}2 \cdot 1 \times 10^{4} \\
\mathbf{3 . 5} \times \mathbf{1 0 4} \\
9 \cdot 0 \times 10^{4}\end{array}$ & $\begin{array}{c}4.4 \times 10^{4} \\
\ldots\end{array}$ \\
\hline $\begin{array}{l}\text { Washed and resuspended in } \\
\text { saline }\end{array}$ & $6.6 \times 10^{5}$ & 38 & $2.5 \times 10^{5}$ & $\begin{array}{l}2 \cdot 2 \times 10^{4} \\
3.2 \times 10^{4} \\
7 \cdot 8 \times 10^{4}\end{array}$ & $\begin{array}{c}3.2 \times 10^{4} \\
\ldots\end{array}$ \\
\hline $\begin{array}{l}\text { Washed, resuspended and } \\
\text { heated at } 70^{\circ} \mathrm{C} \text { for } 20 \mathrm{~min} \text {. }\end{array}$ & $\ldots$ & $\cdots$ & $\ldots$ & $\begin{array}{l}2 \cdot 0 \times 10^{4} \\
\mathbf{3 . 3} \times 10^{4} \\
7 \cdot 0 \times 10^{4}\end{array}$ & $\begin{array}{c}3 \cdot 2 \times 10^{4} \\
\ldots\end{array}$ \\
\hline
\end{tabular}

\footnotetext{
* Based on the mean of separate observations with phase-contrast microscopy and stained smears.

$\dagger$ The figures derived from results obtained with various dilutions are given to show the degree of variation. The "most reliable estimate" (see Methods) is indicated in bold figures.

$\ldots=$ Not done.
}

Studies on surface cultures with dithiothreitol-cysteine. At this point in our work, Moore reported a complex medium that allowed the surface growth of $\mathrm{Cl}$. oedematiens type B. The significantly active ingredients appeared to be dithiothreitol and cysteine. When these agents were incorporated into a blood agar medium with human blood, the surface growth of $\mathrm{Cl}$. oedematiens of types B and D was greatly facilitated (Watt, unpublished data). This development allowed us to base reliable viable counts on the surface growth of type-D strains. Technical difficulties associated with the spreading growth of strains of types B and C on the surface of solid media obliged us to use type-D strains in the following quantitative studies. We then retested the viable particle hypothesis with Moore's medium modified by Watt (cysteine-dithiothreitol human blood agar, CDHBA16). The inocula were derived from cooked-meat broth cultures grown overnight and unwashed, unless otherwise stated.

The results given in table IV show that viable counts could be obtained on CDHBA from inocula derived from a young (18-hr) culture of $\mathrm{Cl}$. oedematiens 
type $\mathrm{D}$ that were very much greater than the maximum spore estimates. The estimated number of spores increased as the culture aged, but the viable count decreased to 1 per cent. of the estimated number of spores. Thus, it seems clear that the growth of vegetative cells on CDHBA16 accounts for a significant component of the viable counts for young cultures. For a slightly older culture the recovery of vegetative cells was only 2 per cent. of the total count, compared with almost 5 per cent. for the younger culture. These results imply that as a culture ages, the proportion of vegetative cells that can be redeemed on CDHBA16 is

TABLE IV

Total counts, spore counts and surface viable counts of samples of cultures of $C l$. oedematiens (type D) in CMB medium

\begin{tabular}{|c|c|c|c|c|c|c|}
\hline \multirow{2}{*}{$\begin{array}{l}\text { Cultural conditions } \\
\text { of test sample }\end{array}$} & \multirow{2}{*}{$\begin{array}{l}\text { Total } \\
\text { count } \\
\text { per ml }\end{array}$} & \multicolumn{3}{|c|}{$\begin{array}{l}\text { Percentage of sporing } \\
\text { forms as judged by }\end{array}$} & \multirow{2}{*}{$\begin{array}{c}\text { Estimated } \\
\text { number of } \\
\text { spores } \\
\text { per ml }\end{array}$} & \multirow{2}{*}{$\begin{array}{l}\text { Surface } \\
\text { viable count } \\
\text { per ml on } \\
\text { CDHBA16* } \\
\text { at } 20 \mathrm{hr}\end{array}$} \\
\hline & & $\begin{array}{c}\text { phase } \\
\text { contrast }\end{array}$ & $\begin{array}{c}\text { Gram's } \\
\text { stain }\end{array}$ & $\begin{array}{l}\text { spore } \\
\text { stain }\end{array}$ & & \\
\hline $\begin{array}{l}\text { After incubation for } \\
24 \mathrm{hr}\end{array}$ & $6.7 \times 10^{7}$ & $<0 \cdot 2$ & $\begin{array}{l}0 \cdot 2 \\
0 \cdot 1\end{array}$ & $\begin{array}{l}<0 \cdot 1 \dagger \\
<0.1 \dagger\end{array}$ & $6.7 \times 10^{4} \ddagger$ & $3 \cdot 1 \times 10^{6}$ \\
\hline $\begin{array}{l}\text { After } 24 \text { hours' incuba- } \\
\text { tion }+6 \text { days at room } \\
\text { temperature }\end{array}$ & $2.0 \times 10^{7}$ & 7 & $\begin{array}{l}3 \\
3\end{array}$ & $\begin{array}{l}4 \\
4\end{array}$ & $8.1 \times 105 \S$ & $8.7 \times 10^{3}$ \\
\hline $\begin{array}{l}\text { After } 18 \text { hours' incuba- } \\
\text { tion }+48 \mathrm{hr} \text { at room } \\
\text { temperature }\end{array}$ & $3.0 \times 10^{7}$ & $1 \cdot 6$ & $1 \cdot 1$ & 0.5 & $4.8 \times 10^{5}$ & $5.5 \times 10^{5}$ \\
\hline $\begin{array}{l}\text { After } 18 \text { hours' incuba- } \\
\text { tion }+28 \text { days at room } \\
\text { temperature }\end{array}$ & $1 \times 10^{8} \|$ & c. 90 & $\ldots$ & $\ldots$ & c. $9.0 \times 10^{7}$ & $7 \cdot 0 \times 10^{2}$ \\
\hline
\end{tabular}

* CDHBA16 = Cysteine-dithiothreitol blood agar (see Methods).

$\dagger$ No spores observed in 1000 cells counted.

$\mp$ Based on 0.1 per cent. estimate.

$\S$ Based on 4.0 per cent. estimate.

|| Accurate total counts were impossible; large numbers of spores of a considerable range of size were irregularly distributed. A minimum estimate is given.

$\ldots=$ Not done.

reduced. It is not clear from these results whether viability in old cultures is associated with vegetative cells or with spores; if spores are the significantly viable particles, the proportion that germinate and proceed to successful outgrowth is very small $(0.0008$ per cent. in the study recorded in table IV).

If vegetative cells are being redeemed on CDHBA16 from inocula of young cultures of $\mathrm{Cl}$. oedematiens, they should be susceptible to heat; in addition, the results in table IV suggest that they are also susceptible to washing, and we proceeded to test this. Our findings are summarised in table V.

It was found that pasteurisation reduced the viable count, and this indicates that vegetative cells contributed significantly to the viable count of the untreated culture. A similar reduction could be obtained simply by washing the inoculum 
under normal aerobic conditions with nutrient broth and resuspending it in saline. These results indicate that vegetative cells are vulnerable to heating and washing, and the similar counts obtained after these two separate procedures suggest that no activation of spores occurred at $80^{\circ} \mathrm{C}$. The recovery of vegetative cells was very low in this experiment $(0.04$ per cent.). Spore recovery from the heated culture was 0.01 per cent. of the estimated number of spores.

TABLE V

Counts obtained with treated and untreated samples of a strain of $\mathrm{Cl}$. oedematiens type $\mathrm{D}$ cultured in $\mathrm{CMB}$ medium for $18 \mathrm{hr}$ at $37^{\circ} \mathrm{C}$

\begin{tabular}{|c|c|c|c|c|}
\hline $\begin{array}{l}\text { Pretreatment } \\
\text { of sample }\end{array}$ & $\begin{array}{c}\text { Total cell } \\
\text { count per ml }\end{array}$ & $\begin{array}{l}\text { Observed } \\
\text { percentage of } \\
\text { spores }\end{array}$ & $\begin{array}{c}\text { Estimated } \\
\text { number of } \\
\text { spores per ml }\end{array} \mid$ & $\begin{array}{l}\text { Surface viable count per ml } \\
\text { after } 48 \mathrm{hr}^{*} \text { on CDHBA16 }\end{array}$ \\
\hline $\begin{array}{l}\text { Untreated CMB } \\
\text { culture }\end{array}$ & $1.5 \times 10^{7}$ & $2 \cdot 4$ & $3.6 \times 10^{5}$ & $6.6 \times 10^{3}$ \\
\hline $\begin{array}{l}\text { Culture heated at } \\
80^{\circ} \mathrm{C} \text { for } 20 \mathrm{~min} .\end{array}$ & $\ldots$ & $\ldots$ & $\ldots$ & $\begin{array}{l}\text { Each of three replicate cultures } \\
\text { of } 0.02 \mathrm{ml} \text { gave one colony. } \\
\text { This indicates a count of } \\
50 \text { per ml }\end{array}$ \\
\hline $\begin{array}{l}\text { Culture washed and } \\
\text { resuspended in } \\
\text { saline }\end{array}$ & $1.5 \times 10^{7}$ & $2 \cdot 4$ & $3.6 \times 10^{5}$ & $\begin{array}{l}\text { Three replicate cultures of } \\
0.02 \mathrm{ml} \text { gave two, one and } \\
\text { one colonies. This indicates } \\
\text { a count of } 50-100 \text { per ml }\end{array}$ \\
\hline $\begin{array}{l}\text { Cultured washed, re- } \\
\text { suspended and } \\
\text { heated at } 80^{\circ} \mathrm{C} \text { for } \\
20 \mathrm{~min} .\end{array}$ & $\ldots$ & $\ldots$ & $\ldots$ & $\begin{array}{l}\text { No growth obtained from } \\
\text { three replicate cultures of } \\
0.02 \mathrm{ml}\end{array}$ \\
\hline
\end{tabular}

* All of the replicate cultures were performed with the same batch of medium and incubated in a single anaerobic jar.

$\ldots=$ Not done.

Although pasteurisation might be considered to cause the death of some of the spores, it is less likely that significant numbers of spores were inactivated by washing. That the reduction in viable count was not due to loss of cells during centrifugation is indicated by the unchanged total cell count, but we bear in mind that the confidence limits of such total counts are unfortunately wide. In the results given in table $\mathrm{V}$, it is probably significant that the proportion of spores in the washed suspensions was unchanged and this again implies that there was no real loss of cells during the procedure.

The results given in table $\mathrm{V}$ confirm that the viable cell count of $\mathrm{Cl}$. oedematiens type $\mathrm{D}$ was markedly reduced by pasteurisation and also by the washing and resuspension procedure. When these treatments were combined, there was complete inactivation. This strongly suggests that vulnerable vegetative cells formed the major component of the test inoculum and contributed primarily to the viable count obtained for the untreated material. The similar 
degrees of inactivation that followed pasteurisation and washing, however, led us to the view that the survivors of each individual procedure were spores, but that the proportion of spores that proceed to germination and successful outgrowth is remarkably small.

The results given in table VI are of particular interest; they relate to a culture that contained very few spores. In an inoculum of $0.02 \mathrm{ml}$ of a heated suspension estimated to contain $c .2 \times 10^{5}$ organisms per $\mathrm{ml}$, there seemed to be 99.8 per cent. vegetative forms. Thus only about ten spores would be

TABLE VI

The loss of viability observed after different treatments of samples of a CMB culture of a type-D strain of $\mathrm{Cl}$. oedematiens that was incubated for $18 \mathrm{hr}$ at $37^{\circ} \mathrm{C}$ then held at room temperature for 7 days

\begin{tabular}{l|c|c|c|c}
\hline \multicolumn{1}{c|}{$\begin{array}{c}\text { Pretreatment } \\
\text { of sample }\end{array}$} & $\begin{array}{c}\text { Total cell } \\
\text { count per } \mathrm{ml}\end{array}$ & $\begin{array}{c}\text { Observed } \\
\text { percentage } \\
\text { of spores }\end{array}$ & $\begin{array}{c}\text { Estimated } \\
\text { number of } \\
\text { spores per ml }\end{array}$ & $\begin{array}{c}\text { Surface viable count } \\
\text { per ml* on } \\
\text { CDHBA16 }\end{array}$ \\
\hline Untreated & $2 \cdot 7 \times 10^{7}$ & $0 \cdot 3$ & $8 \cdot 1 \times 10^{4}$ & $>1 \times 10^{4} \dagger$ \\
\hline Heated at $80^{\circ} \mathrm{C}$ for $20 \mathrm{~min}$. & $\ldots$ & $\ldots$ & $\ldots$ & $<50 \ddagger$ \\
\hline $\begin{array}{l}\text { Washed and resuspended } \\
\text { in saline }\end{array}$ & $2 \cdot 4 \times 10^{7}$ & $0 \cdot 2$ & $4.8 \times 10^{4}$ & $<50 \ddagger$ \\
\hline $\begin{array}{l}\text { Washed and resuspended, } \\
\text { then heated at } 80^{\circ} \mathrm{C} \text { for } \\
20 \text { min. }\end{array}$ & $\ldots$ & $\ldots$ & $\ldots$ & $<50 \ddagger$ \\
\hline
\end{tabular}

* All plates were incubated in the same anaerobic jar at $37^{\circ} \mathrm{C}$ for $48 \mathrm{hr}$.

$\dagger$ There was a tendency to confluent growth in all three replicate plates; the count was greater than the figure given.

$\ddagger$ Each of three replicate undiluted samples of $0.02 \mathrm{ml}$ yielded no growth.

$\ldots=$ Not done.

present in $0.02 \mathrm{ml}$, and we already know that the germination rate is poor. The essentially vegetative inoculum was thus completely inactivated by each of the procedures employed.

These theories were examined in a further series of experiments in which a young spore-deficient culture of $\mathrm{Cl}$. oedematiens type $\mathrm{D}$ was studied in parallel with an older culture in which sporulation had occurred. Results of other studies in this laboratory meanwhile encouraged us to fit each anaerobic jar with three catalyst sachets.

A $0 \cdot 1-\mathrm{ml}$ inoculum from a 16-hr culture of $\mathrm{Cl}$. oedematiens type $\mathrm{D}$ was used to seed fresh anaerobic CMB medium at $37^{\circ} \mathrm{C}$. The new culture and the parent culture were reincubated for $5 \mathrm{hr}$. Total cell counts and spore estimates were performed with samples of the 5-hr and $21-\mathrm{hr}$ cultures. Samples of each culture were pasteurised at $70^{\circ} \mathrm{C}$ and at $80^{\circ} \mathrm{C}$ for $20 \mathrm{~min}$. In addition, samples of each culture were diluted serially in presteamed nutrient broth and viable counts were performed on (i) human blood agar (HBA) now containing 33 per cent. blood, (ii) human blood agar sprinkled subsequently with iron filings 
(HBAIF), (iii) Watt's cysteine-dithiothreitol blood agar (CDHBA33), and (iv) CDHBA33 sprinkled with iron filings (CDHBAIF). The increased concentration of blood had been found to produce slightly better growth of the test organism.

The results are summarised in table VII. The 5 -hr culture contained $3.6 \times 10^{6}$ viable particles per $\mathrm{ml}$ and the spore content was estimated at less than 0.2 per cent. $\left(<9.0 \times 10^{3}\right.$ per $\left.\mathrm{ml}\right)$. This culture yielded appreciable growth on HBA, but the colonies were small. Growth was better on HBAIF, much better on

\section{TABLE VII}

The observed viability of duplicate samples of 5-hr and 21-hr CMB cultures of Cl. oedematiens type $\mathrm{D}$ before and after pasteurisation at $70^{\circ} \mathrm{C}$ and at $80^{\circ} \mathrm{C}$ with recovery on different media

\begin{tabular}{|c|c|c|c|c|c|}
\hline \multirow{2}{*}{$\begin{array}{l}\text { Time of } \\
\text { incubation } \\
\text { of sample } \\
\text { (hr) }\end{array}$} & \multirow{2}{*}{$\begin{array}{l}\text { Treatment } \\
\text { of sample }\end{array}$} & \multicolumn{4}{|c|}{ Surface viable count per ml estimated from cultures grown on $\uparrow$} \\
\hline & & HBA $\ddagger$ & HBAIF & CDHBA & CDHBAIF \\
\hline \multirow[t]{3}{*}{$5^{*}$} & None & $(6 \cdot 5-6 \cdot 6) \times 10^{4}$ & $(1 \cdot 3-1 \cdot 4) \times 10^{5}$ & $(2 \cdot 6-3 \cdot 0) \times 10^{5}$ & $(4 \cdot 2-5 \cdot 3) \times 10^{5}$ \\
\hline & $\begin{array}{l}\text { Heated at } 70^{\circ} \mathrm{C} \\
\text { for } 20 \mathrm{~min} .\end{array}$ & $<10,<10$ & $<10,50$ & $<10,<10$ & $<10,10$ \\
\hline & $\begin{array}{l}\text { Heated at } 80^{\circ} \mathrm{C} \\
\text { for } 20 \mathrm{~min} .\end{array}$ & $<10,<10$ & $<10,20$ & $<10,<10$ & $<10,<10$ \\
\hline \multirow[t]{3}{*}{21} & None & $>5 \times 10^{4} \S$ & $(3 \cdot 7-4 \cdot 3) \times 10^{6}$ & $(3 \cdot 6-3 \cdot 9) \times 10^{6}$ & $(4 \cdot 6-5 \cdot 7) \times 10^{6}$ \\
\hline & $\begin{array}{l}\text { Heated at } 70^{\circ} \mathrm{C} \\
\text { for } 20 \mathrm{~min} .\end{array}$ & $<10,<10$ & $(1 \cdot 6-2 \cdot 2) \times 10^{3}$ & $(2 \cdot 8-2 \cdot 9) \times 10^{2}$ & $(1 \cdot 08-1 \cdot 12) \times 10^{3}$ \\
\hline & $\begin{array}{l}\text { Heated at } 80^{\circ} \mathrm{C} \\
\text { for } 20 \mathrm{~min} .\end{array}$ & $<10,<10$ & $(7 \cdot 3-7 \cdot 8) \times 10^{2}$ & 90,120 & $(4 \cdot 9-7 \cdot 1) \times 10^{2}$ \\
\hline
\end{tabular}

* At $5 \mathrm{hr}$ the total cell count was $3.6 \times 10^{6}$ per ml, and the spore estimate was $<9.0 \times 10^{3}$ per ml.; at $21 \mathrm{hr}$ the corresponding figures were $8.0 \times 10^{6}$ and $4.3 \times 10^{5}$.

$\dagger \mathrm{HBA}=$ Human blood agar containing 33 per cent. blood; HBAIF $=$ HBA sprinkled with iron filings; $C D H B A=$ HBA supplemented with cysteine and dithiothreitol; $C D H B A I F=$ CDHBA sprinkled with iron filings.

$\ddagger$ This medium yielded tiny colonies.

$\S$ Minimum count based on profuse growth of $c .1000$ discrete colonies from $0.02 \mathrm{ml}$ of undiluted sample; cultures from 10-fold dilutions yielded no growth on HBA medium.

CDHBA and very much better on CDHBAIF. Replicate results showed a consistent gradation; thus, the recovery of vegetative cells on these media was $1 \cdot 8,3 \cdot 9,7 \cdot 8$ and 13.3 per cent. respectively. All of the viable counts exceeded the spore estimate of $<9.0 \times 10^{3}$ per $\mathrm{ml}$; the viable count with CDHBAIF $\left(4.7 \times 10^{5}\right.$ organisms per $\left.\mathrm{ml}\right)$ was at least 50 times greater than the spore estimate. When the young culture was pasteurised at $70^{\circ} \mathrm{C}$, only one colony was recovered from $0.1 \mathrm{ml}$ of the undiluted sample on a CDHBAIF plate and five colonies on an HBAIF plate. After pasteurisation at $80^{\circ} \mathrm{C}$, two colonies were cultured on an HBAIF plate. We therefore assume that if heat-resistant spores were being redeemed in the pasteurised series, they were very few and they required iron filings at some stage of germination or outgrowth. 
The results obtained with the 21-hr culture were significantly different (table VII). This older culture contained $8.0 \times 10^{6}$ viable particles $\mathrm{per} \mathrm{ml}$ and the spore content, estimated at 5.3 per cent., was $4 \cdot 3 \times 10^{5}$ per ml. Samples yielded growth on HBA only when the inoculum was undiluted; very good growth was obtained with diluted samples on HBAIF, CDHBA and CDHBAIF: the recovery of vegetative cells was 50,48 and 65 per cent. respectively. All the viable counts obtained with the latter three successful systems exceeded the spore estimate approximately 10 -fold; the best count $\left(5 \cdot 2 \times 10^{6}\right.$ per $\left.\mathrm{ml}\right)$ was remarkably near the total cell count $\left(8.0 \times 10^{6} \mathrm{per} \mathrm{ml}\right)$. When samples of the $21-\mathrm{hr}$ culture were pasteurised, it was clear that HBA alone does not redeem spores. Spore recovery on HBAIF, CDHBA and CDHBAIF was 0.4, 0.07 and 0.3 per cent. respectively for cultures heated at $70^{\circ} \mathrm{C}$; spore recovery in cultures heated at $80^{\circ} \mathrm{C}$ was $0.2,0.02$ and 0.1 per cent. respectively. The results suggest that some of the spores are vulnerable to heating at $80^{\circ} \mathrm{C}$. Best recoveries were obtained with HBAIF, and there was clear evidence that the cysteine-dithiothreitol (CD) system was inferior for spore recovery in this model. When CDHBAIF was used, the CD component seemed to inhibit some of the stimulatory effect of the iron filings. There was no evidence of heat activation of the spores at the temperatures tested $\left(70^{\circ}-80^{\circ} \mathrm{C}\right)$. The best yield in the pasteurised series was obtained from the sample heated at $70^{\circ} \mathrm{C}$; this gave a viable count of $2.2 \times 10^{3}$ per $\mathrm{ml}$ when recovered on HBAIF. This represents less than 0.5 per cent. of the total spore estimate. We therefore conclude that more than 99 per cent. of the spores in this model remain dormant or are nonviable (table VII).

If the above views are correct, it seems important to note that samples of a 5 -hr culture yielded growth on simple HBA equivalent to a viable count of $(6 \cdot 5-6 \cdot 6) \times 10^{4}$. This is clear evidence that vegetative forms can be successfully subcultured on a relatively simple fresh medium. However, growth of $\mathrm{Cl}$. oedematiens type D on HBA is unreliable and colonies are very much smaller than those grown on the special media. Moreover, the evidence summarised in table VII suggests that young cells benefit from a complex of protective mechanisms, whereas older cells may be slightly less exacting.

\section{Discussion}

The present study obliged us to review our anaerobic jar procedure; it is clear that practical details and correct maintenance of equipment may be neglected or overlooked unless a demanding anaerobe is cultured as a routine test in the laboratory. The standard procedure that we developed seems to be satisfactory, but there is still room for improvement.

Our studies confirm that the culture of Clostridium oedematiens type A on solid media is much more readily achieved than that of strains of types B, C and D. With the latter " difficult " types, the present findings indicate that the problem of successful surface growth of $\mathrm{Cl}$. oedematiens is related primarily to a requirement for anaerobic or reducing conditions; however, we find it difficult to separate this aspect from the organism's nutritional requirements. 
It is well recognised that culture in fluid media is generally achieved more readily than culture on solid media. With types $\mathrm{B}, \mathrm{C}$ and $\mathrm{D}$, growth in broth is fairly easily achieved provided that (i) meat particles are present in the fluid medium, or (ii) an adequate volume and depth of freshly prepared presteamed medium is provided.

The use of iron for the enhancement of growth of anaerobes has been recommended by many workers, but we know of no instance in which particulate iron has been applied to the surface of solid media. Our results provide convincing evidence that this procedure increases the reliability and speed of culture of $\mathrm{Cl}$. oedematiens of types B and D on solid media. The mechanism involved is not clear, though it is reasonable to suggest that it is related to reducing effects at the surface of the medium. We were unable to produce the effect with other metals in particulate form, and the application of various salts of iron to the surface of the medium did not produce the enhancement of growth associated with iron filings. The effect is obtainable when the organisms are incorporated in the agar with iron sprinkled on the surface, but there is no enhancement of growth when organisms are plated on the surface of a medium in which iron filings have been incorporated at the melted stage. Thus, it seems necessary for the iron to be exposed to the atmospheric conditions in the jar at the surface of the medium.

We initially thought that spores may be the significantly viable particles in the inoculum and that the iron is involved in providing suitable conditions for the successful germination or outgrowth at a critical stage in colonial development. At this point we had developed a pour-plate system supplemented with iron filings. The procedure involved transient exposure of the inoculum to temperatures of $40^{\circ}-45^{\circ} \mathrm{C}$. We frequently used old stationary-phase sporing cultures and in some cases we washed the centrifuged bacterial deposit aerobically. All of these factors operate against the survival of vegetative cells and it is now clear that the design of these early experiments was heavily weighted against disproof of the hypothesis that spores are the only significantly viable particles. In these studies it is quite possible that spores contributed significantly to the viable counts, but it was evident that many spores did not produce colonies. With a type-D strain, however, spore recovery in this system greatly exceeded the recovery obtained subsequently at the surface of human blood agar plates supplemented with iron filings.

Our later findings prove conclusively that spores are not the only viable particles when surface colonies are grown from broth cultures. There is clear evidence that we grew surface colonies of $\mathrm{Cl}$. oedematiens type $\mathrm{D}$ from vegetative non-sporing cells on blood agar when iron filings were present on the surface or when the cysteine-dithiothreitol system of Moore (1968) was incorporated in a modified medium developed by Watt. In addition, surface colonies were redeemed from vegetative cells on simple blood agar medium (table VII); growth occurred only with the undiluted samples, and it may be that protective factors are carried over in the broth and allow recovery of vegetative cells under these circumstances.

Some of the viable counts that we obtained were of the same order as the 
maximum spore estimates. On a significant number of occasions, however, the viable counts greatly exceeded the spore estimates. The above evidence must be considered along with the consistent finding that a very small proportion of spores proceeded to successful germination and outgrowth with ultimate colony formation. We do not know the point at which failure of spore redemption occurs, but we accept that more than 99 per cent. of the apparent spore population regularly does not produce surface colonies in our type-D model. The only study that did not show similar results was our experiment with the type-C strain, which seemed to be much more efficient, but this was a pour-plate experiment. Our studies included many attempts to ensure against underestimation of spore numbers. The estimates given are based on a colonyforming-unit counting procedure that gives maximum rather than minimum indices of spore proportions. We acknowledge that free spores may occasionally pass undetected, though we sought to avoid this by examining stained smears in parallel with phase-contrast preparations.

If colony production from the type-D spores is as inefficient as our findings indicate, there must be a very considerable contribution from vegetative forms to the surface viable counts that we regularly obtained, especially from young cultures. The evidence that surface viable counts decrease as spore proportions increase implies either (i) that vegetative cells are the primary component of the viable count and, as they die in ageing culture, they contribute successively less, or (ii) that if spores are the primary component, they become progressively more dormant and less readily activated. Our findings strongly suggest that spores were not the primary component of surface viable counts obtained in a significant number of our studies, particularly with young cultures.

The investigation has elucidated some further points of practical importance. The spores of $\mathrm{Cl}$. oedematiens of all types showed no evidence of activation by heat at $80^{\circ} \mathrm{C}$ and some may be inactivated. Young cells of a type-D strain seemed to derive protection from the iron filings system and there was even better recovery of these cells on solid medium when the cysteine-dithiothreitol complex was added. This complementing effect of the two systems was not as evident with older cells.

It might be supposed that the significantly viable particle in the subculture of $\mathrm{Cl}$. oedematiens type D on solid media is the particle that is most tolerant of manipulation in air, but it is now evident that the vegetative cell of this exacting anaerobe can tolerate transient exposure to air and that the spore is not the only insurance involved in its subculture on to solid media. The concept may guide our approaches to the subculture of exacting non-sporing anaerobes; some authorities at present regard the use of an anaerobic cabinet or inert gas flushing procedures as mandatory in the subculture of these organisms.

The past difficulties experienced in the surface growth of $\mathrm{Cl}$. oedematiens type D seem to stem from its remarkably low rate of spore germination and the high vulnerability of its vegetative cells. However, it is now possible to redeem vegetative cells of this strict anaerobe by procedures that avoid the use of an anaerobic cabinet or flushing systems. 


\section{SUMMARY}

The difficulties encountered in the surface growth of Clostridium oedematiens (Cl. novyi) of types B and D were investigated. Best results were obtained when nutrient agar was enriched with human blood (33 per cent.) and supplemented with (i) iron filings sprinkled on the surface of a seeded plate, or (ii) a development of Moore's cysteine-dithiothreitol system incorporated in the medium. The growth-enhancing effects of these two systems were not identical; different degrees of enhancement were obtained with the two systems when test cultures of different ages were used.

The results of quantitative studies with these culture procedures indicate that, although spores of $\mathrm{Cl}$. oedematiens of types A, B, C and D may be significantly viable particles involved in the growth of inocula in pour plates seeded from old cultures in fluid media, large proportions of the surface viable counts obtained from young cultures of type-D strains are regularly derived from vegetative cells. Viable counts obtained with young cultures of type D, the most demanding strains, on solid media greatly exceeded the maximum estimates for the spore content of the inocula used. There is clear evidence that a very large proportion of type-D spores does not proceed to germination or successful outgrowth under the test conditions.

In the course of this study, amendments to the recommended anaerobic jar procedure were developed and a standardised method is described.

This investigation was generously supported by the Agricultural Research Council (Grant AG 15/57) to whom we are indebted. We also acknowledge with thanks funds donated by Pfizer Ltd for special expenses. We are very grateful to Mr Robert Brown for his enthusiastic help and his technical skill. The development of this study also owes much to constructive discussions with Dr W. B. Moore and Dr P. D. Walker of the Wellcome Research Laboratories, and with Professor G. S. Boyd of this University.

\section{REFERENCES}

Albiston, H. E. 1927. Infectious necrotic hepatitis of sheep in Victoria. A braxy-like sheep disease. Austral. J. Exp. Biol. Med. Sci., 4, 113.

Collee, J. G. 1968. In Medical microbiology, ed. by R. Cruickshank, 11th ed. (revised reprint), Edinburgh and London, p. 800.

COOK, A. M., AND LuND, BARBARA M. 1962. Total counts of bacterial spores using counting slides. J. Gen. Microbiol., $29,97$.

Cruickshank, R. 1968. Medical microbiology, 11th ed. (revised reprint), Edinburgh and London.

KePPIE, J. 1944. A study of the antigens and toxins of Clostridium oedematiens and Clostridium gigas by in vitro and in vivo methods. Ph.D. Thesis, Univ. Cambridge.

Meynell, G. G., AND MeYNell, Elinor 1970. Theory and practice in experimental bacteriology, 2nd ed., Cambridge, p. 80.

MOORE, W. B. 1968. Solidified media suitable for the cultivation of Clostridium novyi type B. J. Gen. Microbiol., 53, 415.

Norris, K. P., AND Powell, E. O. 1961. Improvements in determining total counts of bacteria. J. Roy. Microsc. Soc., 80, 107.

RUTTER, J. M. 1968. The occurrence and pathogenicity of Clostridium oedematiens in animals. Ph.D. Thesis, Univ. Edinburgh.

Rutter, J. M., AND Collee, J. G. 1969. Studies on the soluble antigens of Clostridium oedematiens (Cl. novyi). J. Med. Microbiol., 2, 395. 
SMITH, L. DS. 1955. Introduction to the pathogenic anaerobes, Chicago, p. 44.

Willis, A. T. 1964. Anaerobic bacteriology in clinical medicine, 2nd ed., London.

Willis, A. T. 1969. Clostridia of wound infection, London, p. 161.

Williams, B. M. 1962. Black disease of sheep: observations on the disease in mid-Wales. Vet. Rec., 74, 1536.

Williams, B. M. 1964. Clostridium oedematiens infections (Black disease and Bacillary haemoglobinuria) of cattle in mid-Wales. Vet. Rec., 76, 591. 